\title{
Fisheries and fishing effort at the Indigenous reserves Ashaninka/Kaxinawá, river Breu, Brazil/Peru.
}

\author{
Benedito Domingues do AMARAL ${ }^{1}$
}

\begin{abstract}
This article aimed to describe the subsistence fisheries of traditional populations of three ethnic groups, one Ashaninka and two Kaxinawá, lying on the banks of the River Breu. Initially, monitors were trained to fill logbooks with data from fisheries of the villages during an annual cycle (august/1995-august/1996). Based on these data, it was realized an inventory of the most common fish species caught as well as one about the fishing environment. The following results were obtained: i) Indians prefer to use pools, locally known as "poços", for fishing; ii) the most common caught species are the "mandis" (35\%, Pimelodidae), armored catfishes (Loricariidae), specially Hypostomus sp. (25\%), the "curimatá" (9\%, Prochilodus sp.) and the "saburus" (8\%, Curimatidae), among others; iii) the fishing gears that lead to a high rate of fishing are the native "tingui", nets and bow and arrows; iv) fisheries are more intensive during summer; $v$ ) the fishing effort and their associated factors statistically significant in predicting the catches in the Indian Reserve were $f_{1}$ $=$ number of fishermen, $\mathrm{f}_{2}=$ (number of fishermen*total time devoted to fishing), $\mathrm{f}_{3}=[$ (number of fishermen)*(total time devoted to fishing)-(the time displacement)] and the factor villages and fishing gears; vi) although almost all the fisheries are done by walking to the fishing places, catches increase when paddle boats are used; and vii) the most active fishermen belong to Kaxinawá tribe.
\end{abstract}

\section{KEY WORDS}

Amazon; indigenous fisheries; Ashaninka; Kaxinawá; River Breu; Juruá basin.

\section{As pescarias e esforço de pesca na Reserva Indígena Ashaninka/Kaxinawá, rio Breu, Brasil/Peru.}

\begin{abstract}
RESUMO
Este artigo tem o objetivo de descrever a pesca de subsistência das populações tradicionais de uma aldeia Ashaninka e duas Kaxinawá vivendo à beira do rio Breu. Inicialmente, foram treinados monitores para preencher fichas de coleta de dados das pescarias nas aldeias durante um ciclo anual (agosto/1995 - agosto/1996). A partir desses dados realizaram-se os inventários das espécies de peixes capturadas e dos ambientespesqueiros. A análise dos dados foi efetuada por meio de estatística descritiva e exploratória. Os resultados obtidos foram os seguintes: i) os ambientes mais procurados pelos índios foram os poços; ii) as espécies mais capturadas os mandis (35\%, Pimelodidae), os bodes ou cascudos (Loricariidae), com destaque para o bode praiano (25\%, Hypostomus sp.), o curimatã (9\%, Prochilodus sp.) e os saburus (8\%, Curimatidae), entre outros; iii) constatouse que os arreios ou apetrechos de pesca que mais capturam peixes são o tingui (veneno), a tarrafa e o arco/flecha, respectivamente; iv) durante o verão a atividade de pesca é mais intensa; v) as medidas de esforço de pesca e os fatores associados que foram estatisticamente significativos nas predições das capturas na Reserva Indigena foram: $f_{1}=o$ (número de pescadores), $f_{2}=o$ (número de pescadores*tempo total das pescarias) $e f_{3}=o$ [(número de pescadores*tempo total das pescarias)-(o tempo de deslocamento)] e os fatores aldeias e arreios; vi) apesar da maioria das pescarias serem realizadas a pé até os pesqueiros, as capturas são maiores quando a locomoção se dá através de canoa a remo; e vii) os pescadores mais ativos nas pescarias na Reserva Indigena foram os Kaxinawá.
\end{abstract}

\section{PALAVRAS-CHAVE}

Amazônia, Pescarias Indígenas, Ashaninka, Kaxinawá, Rio Breu, Bacia doJuruá. 


\section{ACTA AMAZONICA}

FISHERIES AND FISHING EFFORT AT THE INDIGENOUS

RESERVES ASHANINKA/KAXINAWÁ, RIVER BREU, BRAZIL/PERU.

\section{INTRODUCTION}

Anthropoid interventions in the great rivers of the world are millenary with varying degrees of environmental impacts. The degradation of the biotic integrity (Karr, 1981) of these aquatic ecosystems set in several continents, like the Mississippi River in North America, the River Tietê in South America, the River Nile in Africa and the River Danube in Central Europe, among others (Petrere \&Agostinho, 1993; Bayley, 1995; Barry et al. 1995). On the other hand, many tropical rivers maintain their biotic integrity like the ones in the headstreams of the upper River Juruá above the municipality of Marechal Taumaturgo, Acre State, North of Brazil. The ecosystems in this region maintain the structure and its natural functions, keeping the rate of anthropoid interventions low.

The upper River Juruá groups conservation units with several territories of traditional human populations, like rubber latex extractors villages and the ethnic groups Ashaninka, Kaxinawá, Manchineri, Kulina, Katukina, Nukuni, Jaminawa, Arara, Poyanawá, Yawanawá, among others, that have no contact with the occidental civilization. The Ashaninka is an ethnic group of the linguistic family Arawak who descends from the preAndean Arawak, from the subgroup Kampa. The languages of the Arawak family extend from the Guyana region of the rivers Orinoco, Solimões, and Marãnon until the western part of Mato Grosso State in Brazil (Mendes, 1991). On the other hand, the Kaxinawá group was enslaved by rubber-tappers at the end of the XIX century. Nowadays, this traditional population lives in a social pattern that resembles those from their past colonizers, though they retained their language and customs of their masters. This ethnic group is the largest Indian population of Acre State, with about 4000 people living in nine Indian areas, some of them in Peru, in the upper River Purus and River Caranja. The Kaxinawá belongs to the linguistic family Pano (Aquino \& Iglesias, 1992).

This region in the Amazonian basin still possesses low demographic density, low mining (mainly gold), low farming activity, and low use of hydro energetic resources. The exception is the plan to build the highway BR-364, which will link the cities Rio Branco and Cruzeiro do Sul, in Brazil, that possibly will expand to the Pacific Ocean, after joining the Transamerica highway in Peru. This enterprise is a matter of concern, because of the way it has been developed; it will probably have the possibility of repeating the same expansionist model of the agriculture frontiers done in Rondônia State in the last decades (Aquino, 1997).
Petrere (1992) stated that the economical and social development models adopted in the past decades by the governments to the Amazonian basin were misleading since they did not respected the ecological peculiarities of the region, the soil fragility, the purity of their waters, the health and the well being of the traditional populations. The modern development model assumes a sustainable use of the resource, not only it's merely exploitation. Thus, we shall not repeat in the Amazonian region the motto "destroy first, try to fix after", as it was adopted in Europe, United Stated, Japan and in the southern part of Brazil. Petrere (1992) also stated that we have the moral obligation, as people and as a Nation, of developing the Amazonian region in an equilibrated way. The aim of this work is to describe, compare, and analyze the subsistence fisheries of the traditional populations of the Ashaninka and the Kaxinawá Indian tribes in the Indian reserve that belongs to the River Breu.

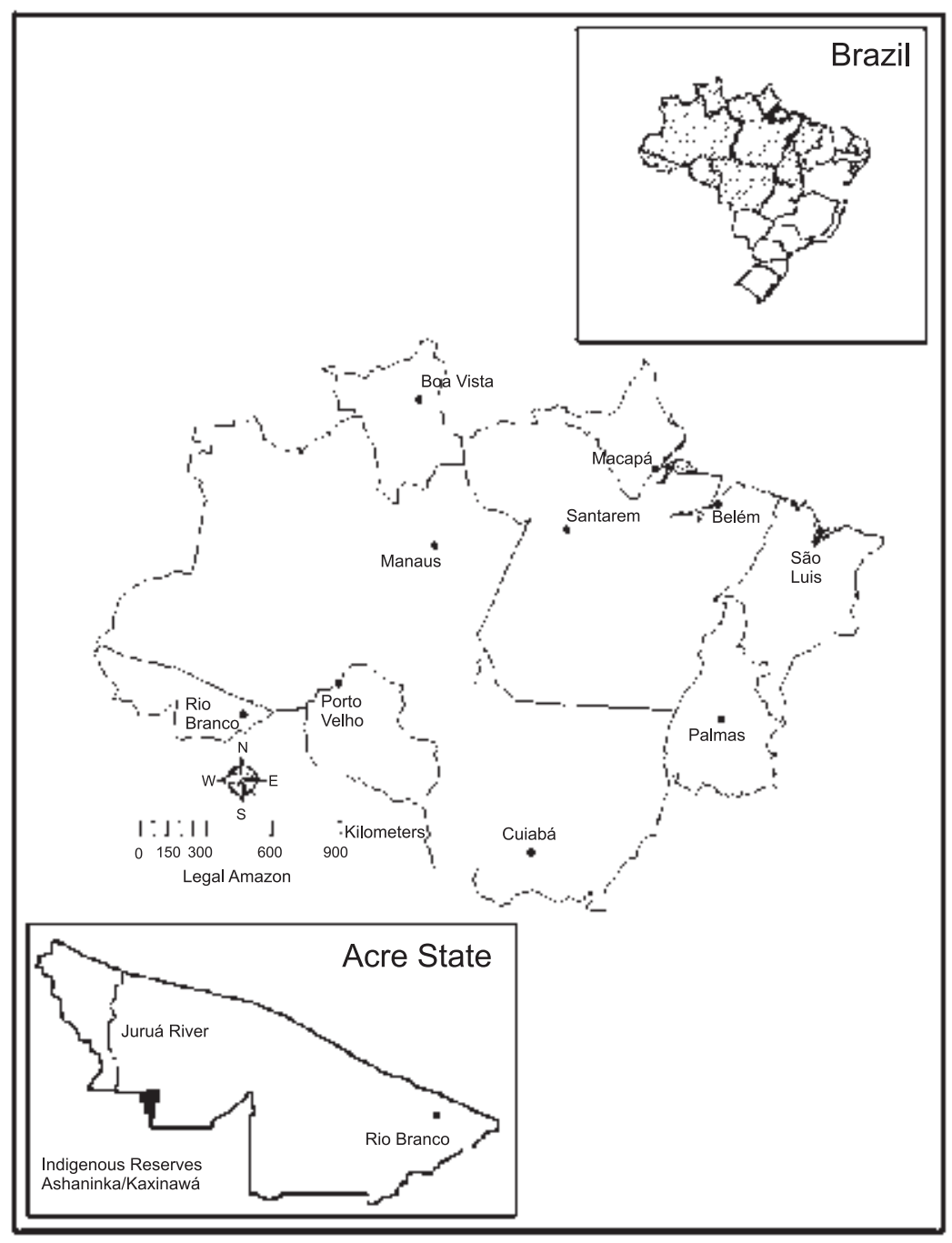

Figure 1 - Study area and its geographical location in Amazon basin. Source: RADAMBRASIL, (1977). 


\section{ACTA \\ AMAZONICA}

\section{MATERIAL AND METHODS}

The study area is in the Indian Reserve AshaninkaKaxinawá, in the River Breu basin, in the frontier of Brazil with Peru (Figure 1). The regional physiography is a dissected and undulated landscape, showing low plateaus covered by open tropical forest and spots of dense tropical forest. The River Breu is a third-order affluent of the alluvial basins of the rivers Javari and upper Juruá. The Indian Reserve lies in the middle and upper Breu River, with an area of 23,840 hectares in the municipality of Marechal Taumaturgo, Acre State, Brazil. The estimated Indian population is 350 inhabitants (Aquino \& Iglesias, 1992). The regional climate consists of rainy (November to May) and dry (June to November) periods, with annual precipitation around 2,224 mm (RADAMBRASIL, 1977).

\section{Sampling of Fisheries Data}

Three teachers who taught in the schools of the Ashaninka and the Kaxinawá villages were responsible for gathering continuous data about the fisheries in the Indian Reserve. They were trained through pilot fisheries, which had the purpose of assembling a routine protocol for data sampling as well as to make the local community used to the development of this study. Sampling of fisheries data in the villages was monitored by a field assistant (November 1995 to July 1996) and by the first author (August 1995 to April 1996). The village houses and the collective fisheries were the sampling units in this study. Fisheries data sampling in the Indian Reserve grouped a hydrological cycle however, due to technical difficulties, data sampling were carried out for 6 months in the Ashaninka village, for 12 months in the Kaxinawá village at Mourão and for 8 months at the Kaxinawá village at Japinim.

\section{Inventory of Fish Species}

The inventory of fish species caught in the basin of the River Breu was done in summer (August 1995) and winter (April 1996) periods, along with the fishing carried out by the inhabitants of the villages. Field inventories provided a lower number of species in relation to those effectively caught in the villages. The author identified the collected species, and voucher specimens were deposited in the Zoological Museum of the University of São Paulo (MZUSP). Taxonomic identification of specimens caught in the villages, but absent in the inventory, were done with the aid of a Fish Catalogue for the studied area provided by Silvano et al. (2000) and Silvano et al. (2001).

\section{Data Analyses}

Information gathered with the fishermen about fisheries and fisheries resources was tabulated with basic statistics (mean, standard deviation), with the purpose of describing some demographic characteristics through estimation and participation of the fishermen during each fishery. For example, fishing duration, number of fishermen per boat, fishing habitats, seasons of high abundance of fish species caught and the most common gears used by them. Initially, fisheries in the villages were analyzed through the index of pondered dominance $\mathrm{ID} \%=\left[\left(\mathrm{P}_{i}^{*} \mathrm{~W}_{i}\right) /\left(\sum \mathrm{P}_{i}^{*} \mathrm{~W}_{i}\right)\right]^{*} 100$, where $\mathrm{P}_{i}$ is the number of individuals and $\mathrm{W}_{i}$ is the weight of the fish species by fishing spot, among villages and by fishing gears (Beaumord, 1991).

The covariance analysis was used to understand how the catches in the Indigenous Reserve were generated from the efforts of fishing gears used by the fishermen of the villages. Data were log transformed to achieve linearity between the response variable (catches) and the explanatory variables (fishing efforts). The covariance model used was as follow:

(eq.1)

$$
\mathrm{Y}_{i j k l m n}=\mathrm{m}+\mathrm{a}_{i}+\mathrm{p}_{j}+\mathrm{q}_{k}+\mathrm{d}_{l}+\mathrm{k}_{m}+\sum_{n=1}^{5} \mathrm{~b}_{n}\left(\mathrm{f}_{i j k l m n}-\overline{\mathrm{f}}\right)+\mathrm{e}_{i j k l m n},
$$

\section{where:}

$\mathrm{Y}_{i j k l m n}$ is the response variable, as described by the catches (kg); $m$ is the overall mean;

$\mathrm{a}_{i}$ is the factor village, with 3 levels: 1- Ashaninka, 2 Kaxinawá at Mourão and 3 - Kaxinawá at Japinim;

$\mathrm{p}_{j}$ is the factor fishing gears with 3 levels: 1- bow and arrow, 2 - nets and 3- native venomous "tingui";

$\mathrm{q}_{k}$ is the factor seasonality, with 2 levels: 1 - summer and 2 - winter;

$\mathrm{d}_{l}$ is the factor kind of locomotion to the fishing spot, with 2 levels: 1 - walk and 2- boat;

$\mathrm{k}_{m}$ is the factor fishery environment, with 4 levels: 1 pools, 2- run, 3 - lakes and 4 - "igarapés"

$\mathrm{b}_{n}$ is the linear coefficient;

$\mathrm{f}_{i j k l m n}$ is the covariate of fishing effort $n=1,2,3,4$, and 5 different units, where $\mathrm{f}_{1}=$ number of fishermen, $\mathrm{f}_{2}=$ number of fishermen*total time devoted to fishing, $\mathrm{f}_{3}=[$ (number of fishermen)*(total time devoted to fishing - the time displacement)]; $\mathrm{f}_{4}=$ number of fishing gears; and $\mathrm{f}_{5}=$ number of fishermen*total time devoted to fishing*number of fishing gears or kilo of "tingui"; f is the covariates means of different fishing efforts; and $\mathrm{e}_{i j k l m n}$ is the random error, supposed $\mathrm{N}\left(0, \mathrm{~s}^{2}\right)$.

As we did not have enough degrees of freedom for testing a full model including all factors interactive and covariates, we needed to break up the analyses in two different ones. The first included the factor villages and fishing gears and covariates. The second included the factor fishing gears, seasonality and locomotion and covariates.

After this, the step-wise analyses were carried out in order to obtain which factors and explanatory variables, concerned the five units of fishing effort were significant to explain the response variable. The second step was to analyze the parallelism between the lines of the response variable, factors, and explanatory covariates, leading to a saturated model. 
Plotting studentizated residuals and the estimated values did sensitivity analysis of the model. A histogram of the normality of the residuals was also plotted, with the asymmetry $\left(\mathrm{g}_{1}\right)$, kurtosis $\left(g_{2}\right)$ tests. Tukey test was used for a comparison between the significant factors in the covariance analysis model with the Indigenous Reserve (Sokal \& Rholf, 1995).

\section{RESULTS}

\section{The Indigenous populations Ashaninka and Kaxinawá}

It can be seen that the Kaxinawá population showed some marked demographic differences compared with the Ashaninka (Table 1). The Ashaninka tribe possesses a younger population with familiar nucleus of about four people and an average of two siblings per family. The anthropoid intervention in the basin by the inhabitant can be considered as minor priority, with emphasis on fishing, hunting, "coivara" agriculture (planting after vegetation burning) and extrativism. In the past years, beans culture has increased for commercialization in the municipality of Cruzeiro do Sul (AC). Nowadays, rubber latex exploration has a low production in the upper area of the reserve in the Kaxinawá village at Japinim. Subsistence fishing and hunting are common among Indian populations. It can be noted an expansion of Kaxinawá community in the Reserve, mainly, after displacements associated with the beginning of the bean agriculture.

\section{Inventory of Fish Species}

In the inventories performed at the Indigenous Reserve, 41 fish species were collected. Other 27 species that were not collected during the sampling period were described by Silvano et al. (2000) and Silvano et al. (2001). Thus, catches in the Indigenous Reserve Ashaninka/Kaxinawá groups 59 species plus one species of crab Sylviocarcinus devillei. The fish species belong to the Order Characiformes, with six families,

Table 1 - Demographic characteristics of the Ashaninka and the Kaxinawá villages.

\begin{tabular}{lccc}
\hline \hline Variables & Ashaninka & $\begin{array}{l}\text { Kaxinawá } \\
\text { at Mourão }\end{array}$ & $\begin{array}{c}\text { Kaxinawá } \\
\text { at Japinim }\end{array}$ \\
\hline $\begin{array}{l}\text { Number of } \\
\text { interviews }\end{array}$ & 11 & 13 & 17 \\
$\begin{array}{l}\text { Mean age } \\
\begin{array}{l}\text { Estimated number } \\
\text { of inhabitants }\end{array}\end{array}$ & 26 years & 34 years & 39 years \\
$\begin{array}{l}\text { Estimated number } \\
\text { of children }\end{array}$ & 22 & 69 & 110 \\
$\begin{array}{l}\text { Average family size } \\
\text { Average number } \\
\text { of children }\end{array}$ & 4 & 43 & 76 \\
\hline \hline
\end{tabular}

Siluriformes, with three families, Gymnotiformes and Perciformes, with two families each and Rajiformes with Potamotrygonidae family (Table 2 ).

\section{Fishing at the Indigenous Reserve}

Three hundred and fifty nine fishing activities were sampled in the Indigenous Reserve, where 96, 176 and 87 trips occurred between the Ashaninka, the Kaxinawá at Mourão, and the Kaxinawá at Japinim villages, respectively. Total catches in the Indigenous Reserve was $2.895 \mathrm{~kg}$ with 44.583 specimens of several species. The most common fish species were the mandis (35\% Pimelodussp.), the bode praiano (25\% Hypostomus sp.), the curimatã (9\% Prochilodus sp.) and, the saburus (8\% Curimatidae), among others. Most of the fishing (72\%) was carried out in pools. Fishing spots with the highest catch were the "Algodão" pool (46\%) in the Kaxinawá village at Mourão, "Mulateiro" (16\%) and "Alho" (4\%) pools, used by fishermen from both the Kaxinawá villages. The "Cuchirir" pool (6\%) was the fishing spot most commonly used by the Ashaninka fishermen. The gears most often used during fishing, accordingly to the season of the year (summer/winter) were:

i) "Tingui" fishing (or fish venom) done with "tingui" plant (locally known as "puikaman" and "siká") in areas inside the forest, with the wild "tingui", which is collected in the forest and can be of different types such as "assacu" milk, "cipó de axá", and leaves of "psymin" and "ninpri". This type of fishing is normally carried out in a collective way in pools during the summer and in the "igarapés" during the winter;

ii) Net fishing, which is carried out during the summer and winter, in a collective way or by a single individual;

iii) Individual fishing during the summer with the aid of bow and arrows;

iv) Use of line and fishhook, which is practiced by single individuals near the houses during the summer and winter, and;

v) Diving fishing with "bicheiro", which consists of a fishhook tied to a large piece of wood. Fishermen dive with this gear, attempting to catch large armored catfishes.

The fishing gears were used in the three villages, apart from the Ashaninka village, where the fishhook was used (Table 3). The mean number of fishermen shows that the "tingui" is the most used collective fishing method, and few fishermen use the fishing with a fishhook. The mean number of fishermen was higher in the Kaxinawá village at Japinim, since this village had the largest population and, relatively fewer fishermen do fishing at the Ashaninka village. Moreover, fishermen at this village spend more time in their fishing sites. Kaxinawá fishermen spend relatively little time to go to their fishing sites. The mean of fishing gears used is higher among the Kaxinawá, specially the "tingui" volume. The highest catches and the average $\mathrm{kg} /$ fisherman are related to the net use in the three villages. The "tingui" showed a high value in caught captured and average $\mathrm{kg} /$ fisherman in the Kaxinawá village at Mourão. Tingui was 


\section{ACTA \\ AMAZONICA

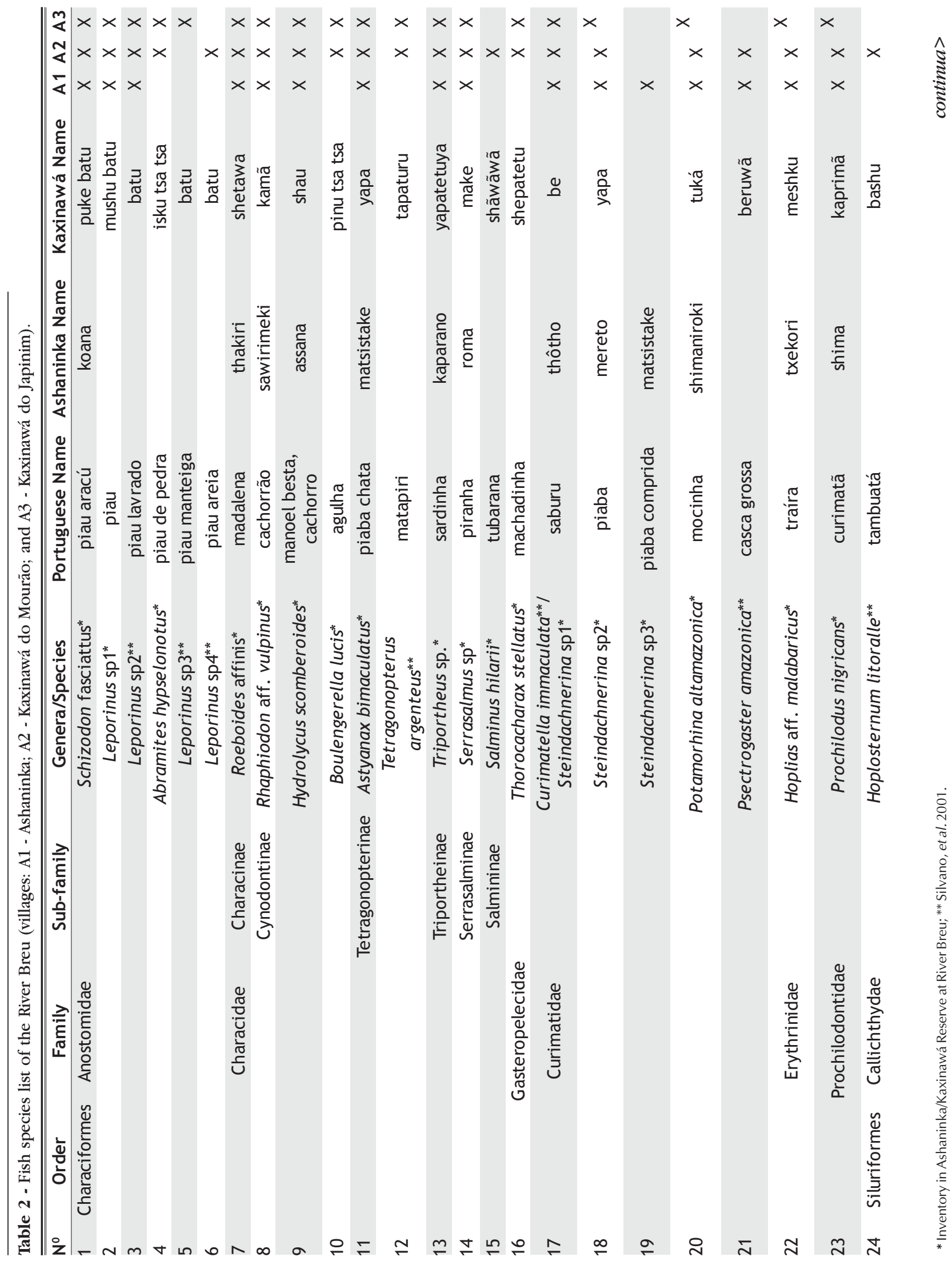



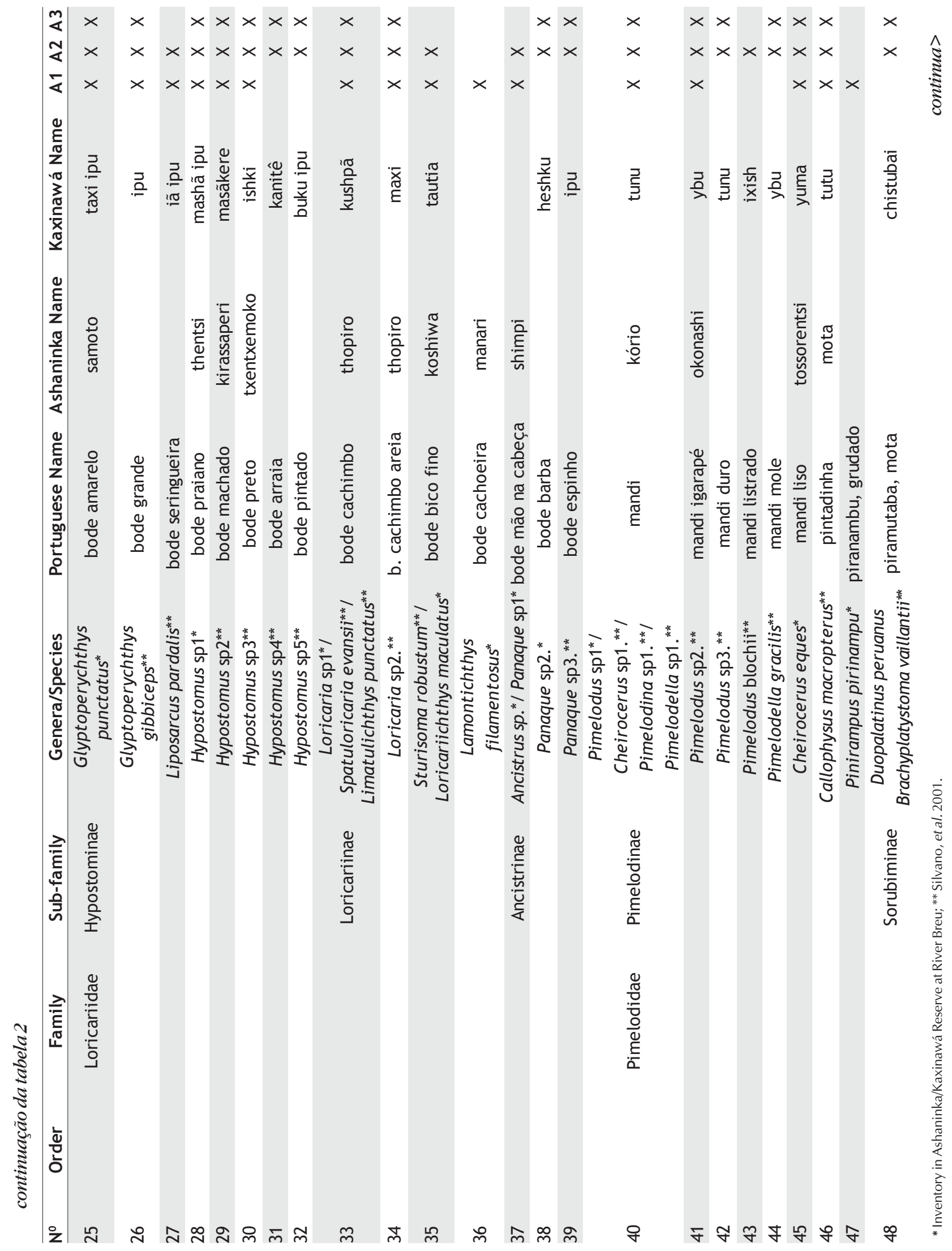


\section{ACTA AMAZONICA}

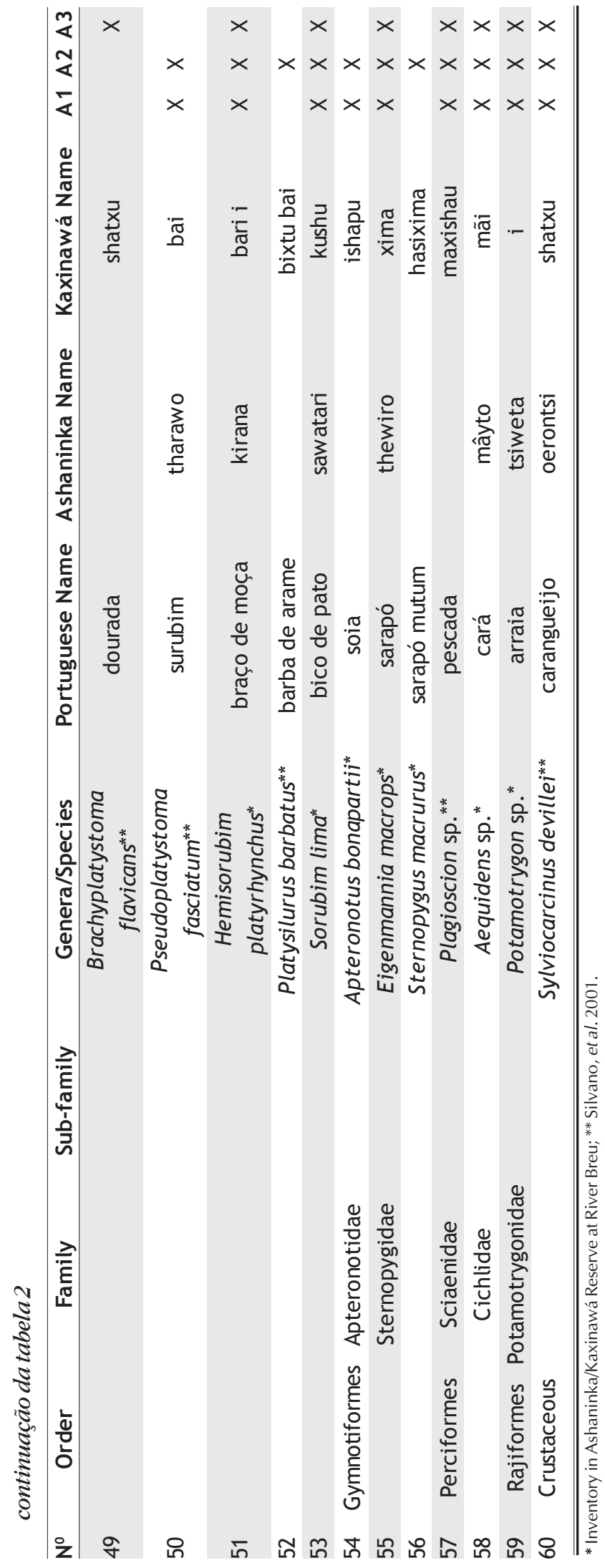

dominant in the Kaxinawá village at Japinim. However, in volume, the caught captured using this method was higher in the Kaxinawá village at Mourão, with $12 \mathrm{~kg}$ per fishing.

\section{Catch variation in the Indigenous Reserve}

Results from the analysis of covariance (ANCOVA) for the Indigenous Reserve are displayed in Tables 4, 5 and Figures 2 and 3. In Table 4, ANCOVA for the factor villages, fishing gears, and fishing effort showed variation in catch $\left(\mathrm{R}^{2}=0.595\right)$. Fishing effort congruent with catch was the $\left(f_{2}\right)$ number of fishermen*total time devoted to fishing and $\left(\mathrm{f}_{3}\right)$ number of fishermen*(total time devoted to fishing - displacement time to fishing sites). Adjusted means for catches showed that higher catches occurred at the Kaxinawá village at Mourão, followed by the Kaxinawá at Japinim and the Ashaninka villages. Adjusted means were higher for "tingui" and nets than for catches using bow and arrows.

Results from ANCOVA for the factors fishing gears, seasonality, and locomotion to fishing sites and fishing efforts for the Indigenous Reserve are in Table 5. Fish catches were significant for all factors analyzed with a $\mathrm{R}^{2}=0.383$. This suggests that, accordingly to the season of the year, the type of locomotion and the used gear had a distinction in fish catches. Fishing effort that showed significance for explaining of catches were $\left(f_{1}\right)$ number of fishermen and $\left(f_{2}\right)$ number of fishermen*total time devoted to fishing. It can be noted that in this covariance model, catches were differentiated between all factors, even between fishing gears. Accordingly, to the adjusted means (seasonal - summer, 3,269kg and winter, 1,635 $\mathrm{kg}$ ), during the summer, catches became more expressive and locomotion by boats is associated with higher catches, although walking does most of the locomotion.

Residuals in the covariance model are shown in Figures 2 and 3 . Some outliers (3 and 4 respective; ${ }^{3} 2$ residuals) were dropped from the analysis and the residuals are normal. Studentized residuals are shown as random points (Figures $2 \mathrm{a}$ and 3a) and histograms of the residuals suggest that they are normal (Figures $2 \mathrm{~b}$ and $3 b$ ).

\section{DISCUSSION}

Fisheries at the Indigenous Reserve Ashaninka/Kaxinawá are strictly devoted to the subsistence of the families, a common pattern in the upper River Juruá and its tributaries (Peres, 1993; Begossi et al. 1999)

A distinction can be noted in the activity of the villages' fishermen during fishing. The Kaxinawá village at Mourão stands out in relation to the Ashaninka and the Kaxinawá at Japinim villages, for its high catch rate, and it is suggested that this fact is related to the every day life of this village.

Catches at the Ashaninka and the Kaxinawá at Japinim villages are lower because these populations devoted more time to collecting and hunting, while the Kaxinawá village at Mourão left behind the rubber latex exploitation to pursue 


\section{ACTA \\ AMAZONICA}

beans agriculture. This pattern was also verified by another population at the upper River Juruá, where only $8 \%$ of the inhabitants devoted their time to rubber latex exploitation, while $92 \%$ are involved with harvesting beans (84\%), corn (71\%) tobacco (51\%), among other plantations (Begossi et al. 1999). Thus, the agriculture starts to have a higher importance, since it starts to be directed towards commercialization.

This fact leads to a stronger dependence on fishing stocks by local people for their daily food intake. Time devoted to hunting tends to decrease, since the probability of finding a prey is smaller than that of catching a fish. Moreover, fishing has a more profitable reward with less time effort than hunting. Accordingly, to Beckerman (1983), fishing has a higher income of protein per hour than hunting, for almost all of the studied cases in Amazon. This trend of shifting from hunting to agriculture by local people may increase the deforestation of the area and lead to an increase effort at fishing sites.

Shifting in the strategies of the use of fishing gears is in accordance with the interactions of the factors village*gears and gears*seasonal*locomotion. Nets and the "tingui" possess the same patterns in the catches for the Kaxinawá villages, no matter the order of magnitude of the catches, with distinction to the catching patterns showed by the gears in the Ashaninka village. On the other hand, the gears (bow/ arrow, nets and "tinguis") were differentiated in catching in relation to the season and locomotion to the fishing sites. These differences are related to the fact that the interaction between gears*locomotion is significant. Fishing with nets tends to be higher when locomotion is by walking, while fishing with "tinguis" tends to have higher catching rates when locomotion is done byboat.

Fishing carried out in the villages at the Indigenous Reserve still exerts a low pressure upon the fishing stocks. The majority of the displacements in the villages are by walking during the summer, although the adjusted means for the catches are higher for displacements by boats. This fact, along with the fishing effort that were

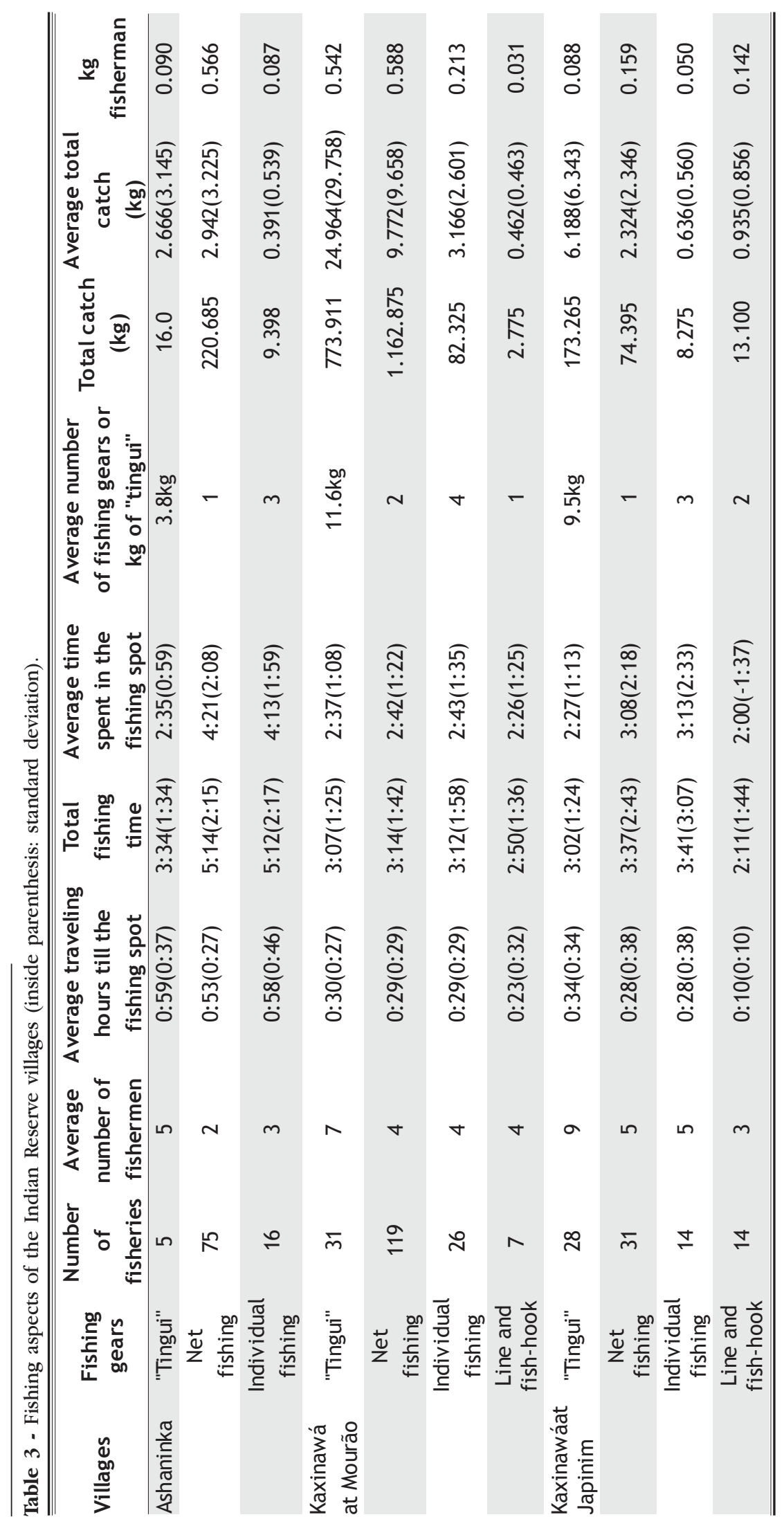




\section{ACTA AMAZONICA}

Table 4 - ANCOVA where the response variable are the catches $(\mathrm{kg})$ and the factors villages and fishing gears and covariates $\mathrm{f}_{2}$ (number of fishermen* total fishing time), $\mathrm{f}_{3}$ [(number of fishermen*total fishing time)-(time displacement)].

\begin{tabular}{|c|c|c|c|c|c|}
\hline \multicolumn{4}{|c|}{ Response variable (catch, kg) N = 352} & $R=0.771$ & $\mathrm{R} 2=0.595$ \\
\hline Source of variation & SQ & GL & MQ & $\mathbf{F}$ & $\mathbf{P}$ \\
\hline Villages & 149.711 & 2 & 74.856 & 82.389 & 0.000 \\
\hline Fishing gears & 95.185 & 2 & 47.592 & 52.382 & 0.000 \\
\hline Villages* Fishing gears & 18.013 & 4 & 4.503 & 4.956 & 0.001 \\
\hline $\mathrm{f} 2$ & 11.241 & 1 & 11.241 & 12.372 & 0.000 \\
\hline f3 & 3.490 & 1 & 3.490 & 3.841 & 0.050 \\
\hline Error & 309.820 & 341 & 0.909 & & \\
\hline
\end{tabular}

Table 5 - ANCOVA where the response variable are the catches $(\mathrm{kg})$ and the factors fishing gears, seasonality and locomotion and the covariates $\mathrm{f}_{1}$ (number of fishermen) and $\mathrm{f}_{2}$ (number of fishermen* total fishing time).

\begin{tabular}{|c|c|c|c|c|c|}
\hline \multicolumn{4}{|c|}{ Response variable (catch, kg) N = 351} & $R=0.619$ & $\mathrm{R} 2=0.383$ \\
\hline Source of variation & SQ & GL & MQ & $\mathbf{F}$ & $\mathbf{P}$ \\
\hline Fishing gears & 94.0550 & 2 & 47.0275 & 34.9824 & 0.000 \\
\hline Seasonality & 28.5739 & 1 & 28.5739 & 21.2553 & 0.000 \\
\hline Locomotion & 9.0816 & 1 & 9.0816 & 6.7555 & 0.009 \\
\hline $\begin{array}{l}\text { Fishing zears* } \\
\text { Locomotion }\end{array}$ & 10.6180 & 2 & 5.3090 & 3.9492 & 0.020 \\
\hline f1 & 13.2620 & 1 & 13.2620 & 9.8652 & 0.001 \\
\hline f2 & 11.3074 & 1 & 11.3074 & 8.4112 & 0.020 \\
\hline Error & 461.1012 & 343 & 1.3443 & & \\
\hline
\end{tabular}

cycles of the Amazon region. The pulse effects concept is the most plausible to explain the fishery productivity in the area of the upper River Juruá. The rain in the winter season is constant and abundant with high variation in water level (7 meters, Barthem, 1995), which leads to the fall of the marginal forest caused by the high forces of the hydraulic power of the river waters. Parts of the headstreams of the rivers still have a meandric pattern, but the development of the pools followed by runs fitted in geological fault systems and the low rupture of the main channel are more frequent in the upper River Juruá. Most of the pools at River Breu, locally know as "balseiros" due to the large amount of trapped fallen trees, were the most visited fishing sites (72\%). The pools sustain a higher fish biomass in comparison with the headstreams of the rivers, where the decrease in alluvial plains leads to a decrease in lake formation. In some rivers, synergistic processes of lake formation (abandoned meandrous or low lakes) are smaller in comparison with large alluvial plain areas, with lower declivity in the area (Tricart, 1977).

According to Morán (1990), flooded areas in upper Amazon River show a higher variability of habitats in comparison with flooded areas in the middle and lower significant in predicting catching rates, showed that the obtained catches depend on the number of fishermen, time devoted to fishing and time spent at the fishing sites. Fishermen maximize their catching capacity only enough to supply food to their families (Beckerman, 1983; Begossi \& Richerson, 1992; Begossi, 1992). Boats are only used when some festive parties happen, when local people get together for harvesting and for fishing of some particular species that when migrating, may increase catching rates.

These results confirm that fishermen optimize their time and strategies during fishing, by choosing environmental conditions that favors the development of fishing at the river basin. Accordingly to Hilborn \& Walters (1992), catches are directly proportional to the efforts of the fishermen during fishing, varying in accordance with time and distance from fishing sites. Bayley (1988) showed that in 59 multi-specific tropical artisan fisheries, fishing efforts are pivotal for fishing income, especially the number of fishermen and time devoted to fishing. Petrere (1978) described the fisheries and fishing effort for the Rei and Janauacá lakes, in Amazonas State, through the CPUE, with emphasis on the effort unit defined by the number of fishermen*days spent fishing.

Junk et al. (1989) stated that the fish biomass productions are related to the lake environment and its adjacent areas that are flooded by the "pulse effects" generated by the hydrological
Amazon River due to the dendritic pattern of the rivers such as Ucayali, Purus and Juruá, where the high number of lakes leads to a high number of microhabitats. Flooded areas and floating vegetation are important for the maintenance of the ichtyofauna diversity supporting these habitats, which allow the food proliferation that sustains the fisheries stocks in the Amazon basin. On the other hand, in rivers at the head of the basin, the flooding areas are smaller, so is the possibility of lake formation. Trapped fallen woods in the bends of the rivers help in pool formation and, thus, aid in the maintenance of a vertical structure in the river water. These "debris" have the capacity to aggregate several species of fish in the pools, with the fixation of the periphyton for the iliophagas species, shelter, resting, and reproduction habitats and, consequently, the presence of predatory species (Tundisi, 1990; Bryant \& Sedell, 1995). These authors further suggest that the presence of fallen woods in the rivers increase the heterogeneity of the habitats by forming aloctonous material banks, shifting the water flow and creating microhabitats for aquatic organisms. Benke (1984 fide Bryant \& Sedell, 1995) studied this type of habitat in the River Satilla (Georgia, USA) and suggested that only $4 \%$ of the areas, which aggregate fallen woods, support about $60 \%$ of the aquatic invertebrates biomass. The congruence among the habitats with a high structural diversity is directly proportional to the diversity in the taxonomic composition (Odum, 1988; Magurran, 1988). 


\section{ACTA \\ AMAZONICA}

FISHERIES AND FISHING EFFORT AT THE INDIGENOUS

RESERVES ASHANINKA/KAXINAWÁ, RIVER BREU, BRAZIL/PERU.

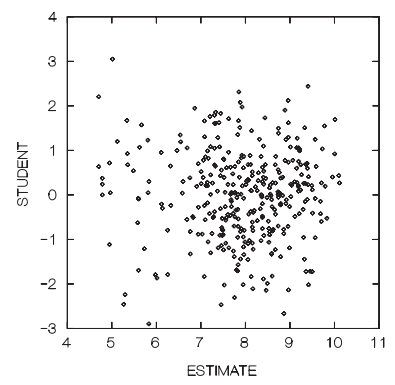

(a)

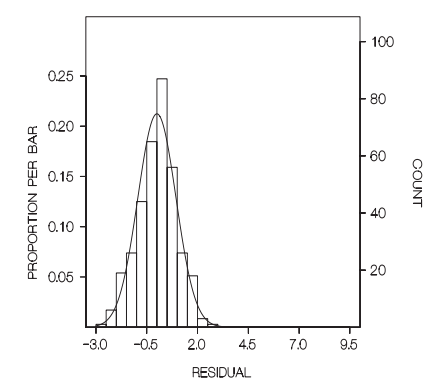

(b)

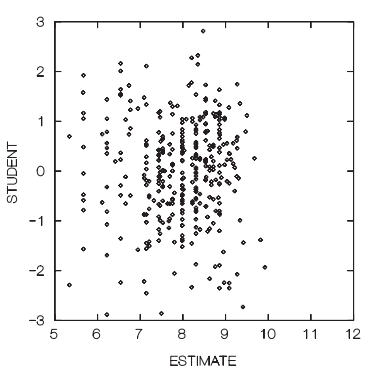

(a)

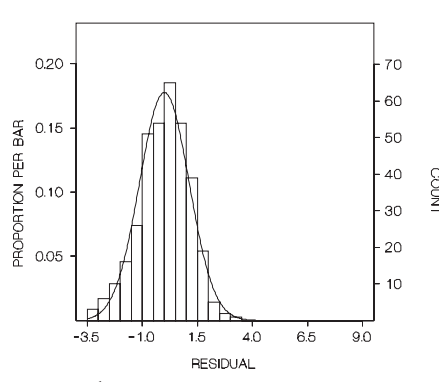

(b)
Figure 2 - Residuals of the ANCOVA where response (dependent) variable are the caches $(\mathrm{kg})$, the factor villages and fishing gears, and covariates $f_{2}$ (number of fishermen* total fishing time), $f_{3}$ [number of fishermen*(total fishing time-time displacement)]. $\mathrm{g}_{1}$ $=-0.133$, ns and $g_{2}=-0.075$, ns. (a) Studentized residuals versus estimated values and (b) histogram of the residuals ( $\mathrm{Y}-\mathrm{Y}$ hat).

All inhabitants of the area highlight the presence of large armored catfishes in the pools at the upper River Juruá. Fishing with "bicheiros" (see below) is a specialized strategy for catching such fish in the pools (Aquino \& Iglesisas, 1992). This gear catches species such as the surubim Pseudoplatystoma fasciatum, the "jundiá" Oxidoras niger, the dourada Bracbyplatystoma flavicans, the piramatuba Brachyplatystoma vaillantii, among others. It is suggested that the presence of such large fish in the pools at the upper River Juruá may be related to the presence of possible reproductive areas, or these species remain in the pools during the non-reproductive season, and then migrate for feeding and dispersing into the floodplains areas of the middle and lower Amazon basin. Fishermen from the Kaxinawá villages at River Jordão and from the Extrativist Reserve of upper River Juruá related that every year there is migration of several species of armored catfish and that the reproductive periods occur with the beginning of the rainy season in October (Begossi et al. 1999; Aquino \& Iglesias, 1992).

Barthem \& Goulding (1997) describe the ecology, migrations, and conservation of the largest armored catfish in the Amazon basin, with special emphasis on the life history of Brachyplatystoma flavicans and B. vaillantii. These two species possess large and non-overlapping home ranges, with feeding, reproductive, and migratory sites inside the Amazon basin. Migration starts in the estuaries and later moves to the main channel of River Amazon, with peaks occurring in September and October. The number of catches confirms this predominance of large armored catfish migration at the upper River Juruá, allied with their occurrence in pools during the summer and, it can be evidence that these species use these areas during their reproductive cycle.

An analogy can be made between the family Salmonidae species from North America and the large catfish of Pimelodidae family in South America, as both groups showed specimens with larger home ranges (Bryant \& Sedell, 1995; Ruffino \& Barthem, 1996). Salmonids use estuaries and marines areas for recruitment and migrate towards the southeast Alaska River.
Figure 3 - Residuals of the ANCOVA where response variable are the caches $(\mathrm{kg})$, the factors fishing gears, seasonality and locomotion and covariates $f_{1}$ (number of fishermen) and $f_{2}$ (number of fishermen* total fishing time). $\mathrm{g}_{1}=-0.269$, ns and $\mathrm{g}_{2}$ $=-0.012$, ns. (a) Studentized residuals versus estimated values and (b) histogram of the residuals ( $\mathrm{Y}-\mathrm{Y}$ hat).

They also use habitats formed by the aggregation of fallen woods as reproductive areas. Sedell et al. (1984, fide Bryant \& Sedell, $1995)$ related that the habitats with fallen woods in the rivers Hoh Fork and upper Queets, USA, are only 6\% and 25\% of all available habitats but respond for the production of $75 \%$ and $55 \%$ of all juveniles salmonids in these rivers respectively. The big stocks of the most important catfish species in the Amazon basin can use habitats with fallen woods in pools as reproductive sites. Barthem \& Goulding (1997) cite that catches of these two species are nearly constant along the year in Letícia, Colombia, with some specimens with eggs being reported. It is known that reproductive migration reaches the heads of the Amazon basin, especially in white water rivers. Authors cite that the higher parts of the Colombia rivers are possible spawning sites for large catfish, especially in the frontier with the Brazilian Amazon.

In case that, the wood exploitation of the agriculture expansion turns to be a fact in this region after the project of highway BR-364 is completed, then the fish stocks may suffer impacts by the sedimentation of the pools, and may lose aloctone material retained in the meandric channels of the alluvial basin of the upper River Juruá (Aquino, 1997). If evidence exists relating the use of pools as reproductive sites by large catfish, the possible impacts due to the highway may change the principles of reproductive cycles of these species, since the synergistic dynamics associated with the pools and lake development in the upper Juruá region will be destroyed (Hilborn et al., 1995).

\section{ACKNOWLEDGMENTS}

To CNPq for the grant, USP for logistic support, NCI Indigenous Culture Center and Austrian Government for financial support of this study, and to Dr. Oswaldo T. Oyakawa, from the Zoological Museum of the University of São Paulo, for helping with taxonomic identification of the fish species. Dr Keith Brown Jr. and Dr Miguel Petrere Jr. for their kindness helping us to participate in a pioneer project in Acre, which opened the opportunity for the present paper. 


\section{LITERATURE CITED}

Aquino, T. T. V.; Iglesias, M. P. 1992. Kaxinawá do Rio Jordão. História, Território, Economia e Desenvolvimento Sustentado. Comissão Pró-Índio do Acre. Setor Gráfico. Rio Branco. Acre. p. 231.

Aquino, T. T. V. 1997. Índios nos corredores ecológicos da Amazônia - Unidades de conservação contínuas. Folba do Meio Ambiente. Folha de São Paulo. São Paulo. p.7-8.

Barry, L. J.; Richardson, W. B.; Naimo, T. J. 1995. Past, Present, and Future Concepts in Large River Ecology. Bioscience 45(3): 134-141.

Barthem, R. B.; Goulding M. 1997. The catfish connection: ecology, migration and conservation of the Amazon predator. Columbia University Press. New York. p.144.

Barthem, R. B. 1995. Development of commercial fisheries in the Amazon Basin and consequences for fish stocks and subsistence fishing. In: Clüsener-Godt, M.; Sachs, I. (eds), Brazilian perspectives on sustainable development of the Amazon region. UNESCO, Man and the Biosphere Series, 15, 9:175-204.

Bayley, B. P. 1995. Understanding large river-floodplain ecosystems. Bioscience 45(3): 153-158.

Bayley, P. B. 1988. Accounting for effort when comparing tropical fisheries in lake, river-floodplains, and lagoons. Limnol. Oceonagr., 33(4, part 2): 963-972.

Beaumord, A. C. 1991. As Comunidades de Peixes do Rio Manso, Chapada dos Guimarães, MT: Uma Abordagem Ecológica Numérica. MSc. Dissertation. UFRJ, Rio de Janeiro. p. 107.

Beckerman, S. 1983. Optimal foraging Group Size for a Human Population: The Case of Bari Fshing. Amerc. Zool., 23: 283-290.

Begossi, A. 1992. The use of optimal foraging theory in the understanding of fishing strategies: A case from Sepetiba bay (Rio de Janeiro State, Brazil). Human Ecology, 20(4): 463-475.

Begossi, A.; Richerson, P. J. 1992. The animal diet of families from Búzios island (Brazil): An optimal foraging approach. Journal of Human Ecology, 3(2): 433-458.

Begossi, A.; Silvano, R. M.; Amaral, B. D.; Oyakawa, O. T. 1999. Uses of fish and game by inhabitants of an Extractive Reserve (Upper Juruá, Acre, Brazil). Environment, Development and Sustainability, 1: 1-21.

Benke A.C. 1984 Secondary Production. In: Resh V.H. \& Rosenberg D.M. (eds.). The Ecology of Aquatic Insects. Praeger Publishing, New York, NY. pp 289-322.

Bryant, M.D.; Sedell, J. R. 1995. Riparian forests, wood in the water, and fish habitat complexity. In: Armantrout N.B. \& Wolotira, Jr. R.J. (eds.). Conditions of the World's aquatic Habitats. Proceedings of the World Fisheries Congress Theme 1. Oxford and IBH Publishing Co. Pvt. Ltd., New Delhi. p. 202-224.

Hilborn, R.; C. J. Walters, 1992. Quantitative Fisheries Stock Assessment: Choice, Dynamics and Uncertainty. Chapman and Hall. New York. p. 570.

Hilborn, R., Walters, C. J.; Ludwig, D. 1995. Sustainable exploitation of renewable resources. Annu. Rev. Ecol. Syst., 26: 45-67.
Junk, W. J.; Bayley, P. B.; Sparks, R. E. 1989. The Flood Pulse Concept in River-Floodplain Systems. Can. Spec. Publ. Fish. Aquatic. Sci. 106: 110-127.

Karr, D. J. 1981. Assessment of biotic integrity using fish communities. Fisheries, 6(6): 21- 27.

Magurran, A. E. 1988. Ecological Diversity and its Mesurement. Groom Helm, London. p. 192.

Mendes, M. K. 1991. Etnografia Preliminar dos Ashaninka da Amazônia Brasileira. MSc. Dissertation. UNICAMP. Campinas. 349 p.

Morán. E. F. 1990. A ecologia bumana das populações da Amazônia. Ed. Vozes. Petropolis. p. 367.

Odum, E. P. 1988. Ecologia. Editora Guanabara S.A. Rio de Janeiro. $434 \mathrm{p}$.

Peres, C. A. 1993. Biodiversity Conservation by Native Amazonians: a Pilot Study in the Kaxinawa Indigenous Reserve ofJordão River, Acre, Brazil. A project report submitted to the World Wildlife Fund, Washington D.C. p. 47.

Petrere, M. J. 1978. Pesca e esforço de pesca no Estado de Amazonas. I- Esforço e captura por unidade de esforço. Acta Amazonica, 8(3): 439-454.

Petrere, M. J. 1992. As comunidades humanas ribeirinhas da Amazônia e suas transformações sociais. In: Diegues, A. C. (ed.), VI Encontro de Ciências Sociais e o Mar no Brasil. Coletâneas de Trabalhos Apresentados.Programa de Pesquisa e Conservação de Äreas Úmidas no Brasil/IOUSP F. Ford, UICN. São Paulo. pp. 31-68.

Petrere, M. J.; Agostinho, A. 1993. La Pesca en el Tramo Brasileño de Rio Paraná. In Taller sobre las pesquerias de la Cuenca del Prata. Comision para la Pesca Continental de America Latina. Montevideo. pp. 52-72.

RadamBrasil, 1977. Folhas SB/SC, 18 Javari/Contamana; geologia, geomorfologia, pedologia, vegetação e uso potencial da terra. Departamento Nacional da Produção Mineral. Levantamento dos Recursos Naturais. Ministério das Minas e Energia. Rio de Janeiro. p. 420.

Ruffino, M. L.; Barthem, R. B. 1996. Perspectivas para el manejo de los bagres migradores de la Amazonia. Santa Fé de Bogotá. Boletin Científico, 4: 19-28.

Sedell, J.R.; Yuska, J.E.; Speaker, R.W. 1984. Habitats and salmonid distribution in pristine, sediment-rich river valley systems: S. Fork Hoh and Queets River, Olympic National Park. In: Meehan, W.R.; Merrell, T.R., Jr.; Hanley, T.A., eds. Fish and wildlife relationships in old-growth forests. Juneau, AK: American Institute of Fisheries Research Biologists: 33-46.

Silvano, R. A. M., Amaral, B.D.; Oyakawa, O.T. 2000, 'Spatial and temporal patterns of diversity and distribution of the Upper Juruá River fish community (Brazilian Amazon)', Environmental Biology of Fishes 57: 25-35.

Silvano, R. A. M.; Oyakawa, O. T.; Amaral, B. D.; Begossi, A. 2001. Peixes do Alto Rio Juruá (Amazonas, Brasil). FAPESP. Editora da Universidade de São Paulo. Imprensa Oficial do Estado. São Paulo. 304p. 
Sokal, R. R.; Rohlf, F. J. 1995. Biometry. Third ed. Freeman San Francisco. p. 887.

Tricart, J. 1977. Ecodinâmica. Rio de Janeiro: IBGE. p. 91.

Tundisi, J. G. 1990. Conservation and Management of Continental Aquatic Ecosystems in Brazil. In: Hongliang, L.; Yutian, Z.; Haisheng, L. (eds.). Lake Conservation and
Management. Proceedings of The 4th International Conference on The Conservation And Management of Lakes "Hangzhou'90". pp. 573-584.

RECEBIDO EM 16/10/2001

ACEITO EM 14/03/2005 